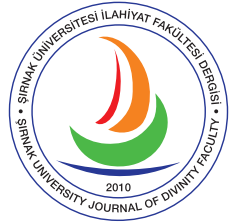

e-ISSN 2667-6575
Şırnak University

Journal of Divinity Faculty

Volume: 10, Issue: 22, June 2019

\title{
Din Kültürü ve Ahlak Bilgisi Öğretmenlerinin Demokratik Tutumları
}

Democratic Attitudes of Religious Education Teachers

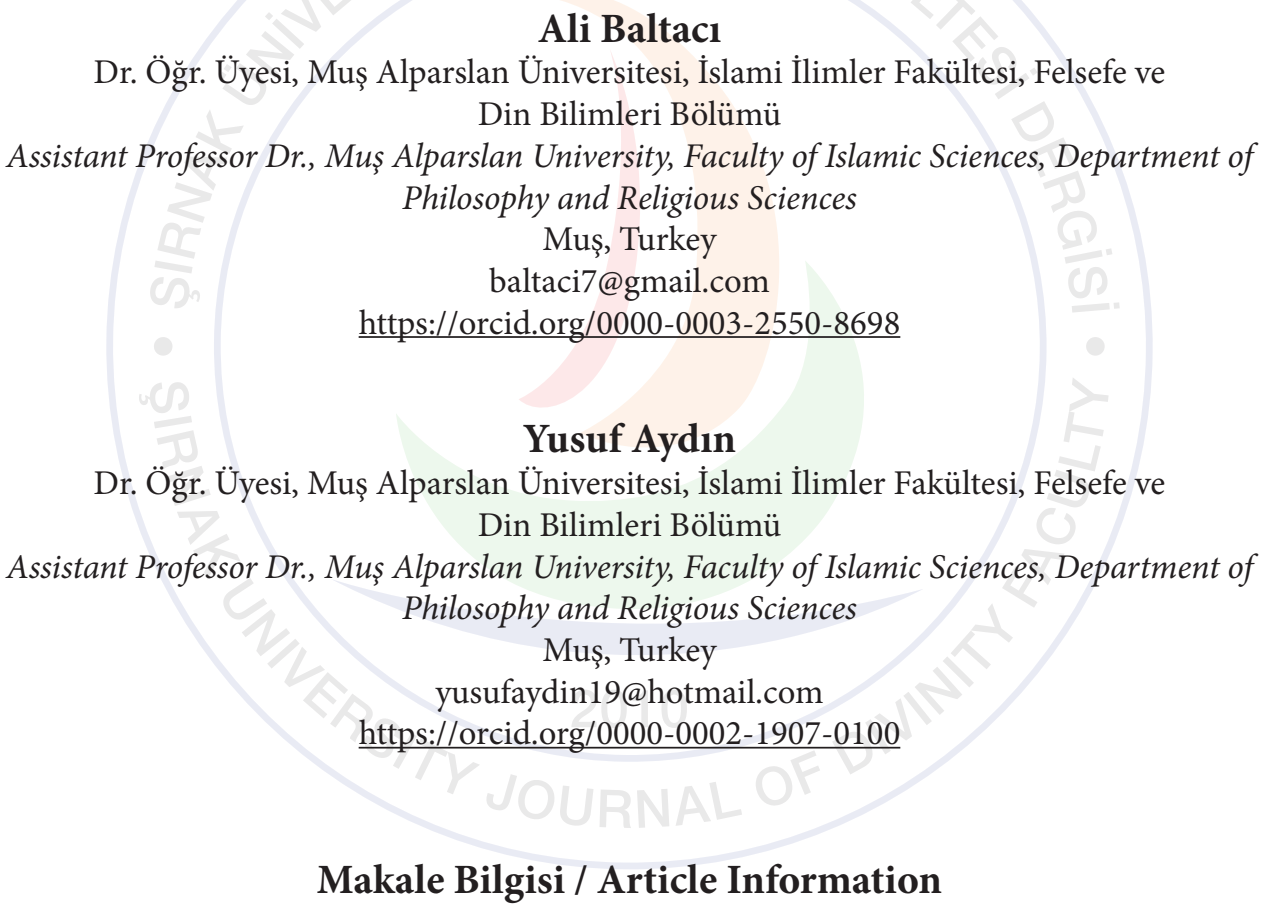

Makale Türü / Article Types: Araștırma Makalesi / Research Article

Geliş Tarihi / Received: 15 Ocak / January 2019

Kabul Tarihi / Accepted: 27 Mart / March 2019

Yayın Tarihi / Published: 15 Haziran / June 2019

Cilt / Volume: 10 Sayı / Issue: 22 Sayfa / Pages: 58-78

Atıf / Cite as: Baltacı, Ali - Aydın, Yusuf. "Din Kültürü ve Ahlak Bilgisi Öğretmenlerinin Demokratik Tutumları [Democratic Attitudes of Religious Education Teachers]”. Şırnak

Üniversitesi İlahiyat Fakültesi Dergisi - Şırnak University Journal of Divinity Faculty 10/22 (June 2019): 58-78.

https://doi.org/10.35415/sirnakifd.470026

Copyright (C) Published by Şırnak Üniversitesi, İlahiyat Fakültesi / Şırnak, Türkiye (Şırnak University, Faculty of Divinity, Şırnak, 73000 Turkey). All rights reserved. 


\title{
Öz
}

$\mathrm{Bu}$ çalışmanın temel amacı din kültürü ve ahlak bilgisi (DKAB) öğretmenlerinin demokratik tutumlarının farklı değişkenler açısından belirlenmesidir. Nicel araştırma deseninde tasarlanan bu araştırmanın çalışma grubu, Ankara İlinde çalışan 349 din kültürü ve ahlak bilgisi öğretmenidir. Araştırmada, Gözütok (1995) tarafından uyarlanan "Demokratik Tutum Ölçeği” kullanılmıştır. Ölçme aracı ile toplanan veriler, betimsel analizler kullanılarak yorumlanmıştır. Araştırma sonunda din kültürü ve ahlak bilgisi (DKAB) öğretmenlerinin demokratik tutum seviyelerinin cinsiyete, eğitim durumuna ve mesleki kıdeme göre farklılaştığı belirlenmiştir. Araştırma sonuçlarına göre kadın öğretmenler, erkek öğretmenlere; lisansüstü eğitim mezunları, lisans mezunlarına göre daha fazla demokratik tutum sergilemektedirler. Mesleki kıdemdeki artış, demokratik tutumları azaltmaktadır. Bu çalışma, 2023 Eğitim vizyon belgesinde yer alan kök değerlerden olan demokratik değerlerin din kültürü ve ahlak bilgisi öğretmenleri tarafından benimsenme derecesini belirlemesi açısından önem arz etmektedir. Literatürde farklı türden demokratik tutum çalışmaları olsa da bu çalışma eğitim sistemi içinde profesyonel olarak çalışmakta olan din kültürü ve ahlak bilgisi öğretmenlerinin demokratik tutumlarının belirlenmesi ile din, din eğitimi ve demokrasi kavramları arasında sürdürülen tartışmaların seyrine etki etmesi bakımından önemli veriler sunmaktadır.

Anahtar Kelimeler: Din Eğitimi, Demokrasi, Tutum, Demokratik Tutum, Öğretmen

\begin{abstract}
The main purpose of this study is to determine the democratic attitudes of religious education (RE) teachers in terms of different variables. The sample group of this research designed in the quantitative research is 349 religious education (RE) teachers working in Ankara province. The "Democratic Attitude Scale" adopted by Gözütok (1995) was used in the research. The data obtained via scales were interpreted by using descriptive analyses. At the end of the research, it was determined that the democratic attitudes of religious education (RE) teachers differed according to sex, educational status, and professional tenure. According to the results of the research, female teachers are more democratic than male teachers; the level of graduate education is more democratic than the undergraduate level. The increase in professional tenure reduces democratic attitudes. This study is important in terms of determining the degree of adoption of the values of the democratic values, which are the root values in the 2023 Educational vision document, by religious education teachers. Although this is a different kind of democratic attitude studies in the literature, this study presents important data in terms of determining the democratic attitudes of religious education teachers who work as a professional in the education system and the effects of the debates between the concepts of religion, religious education and democracy.
\end{abstract}

Keywords: Religious Education, Democracy, Attitude, Democratic Attitude, Teacher 


\section{GİRIŞ}

Modern çağın en önemli kazanımı, düşünce, inanç ve girişim özgürlüklerinin var olduğu bir ortamı gerektiren, bilinmeyene yönelip onu açıklama çabasını güden bilimsel davranıştır. Temel özgürlüklerin sağlanamadığı bir ortamda bilimsel bilgi üretilemediği gibi bu eksiklik farklı kaynaklardan bilgi transferi ile giderilir. Bilginin özgür bir ortamda üretilmeyip sadece nakledilmesi ise bilimsel taklit veya malumun tekrarı anlamına gelmektedir. Böylesi bir durumdan sakınmanın olası yollarından biri de sürdürülebilir millî değerlere saygıllı, çağdaş bir eğitim politikasının uygulanmasıdır. Bu noktada demokrasi, hoşgörü temelli düşünsel yapısı ve özgür düşünceyi destekleyen doğası gereği önemli bir konumdadır.

Demokrasi kavramına yüklenen anlam çeşitliliği, kavramın tam olarak ne anlam ifade ettiği noktasında görüş farklıllı̆̆ yaratmış'; esasen bir yönetim şekli olan demokrasi kavramı², özgürlük ve eşitlik kavramlarını kapsayacak bir anlam çeşitliliğine kavuşmuştur. ${ }^{3}$ Köken olarak antik Yunancadaki demos (halk) ile kratos (yönetim) sözcüklerinin birleşimi ile oluşan kavram ${ }^{4}$, bireylerin hak ve özgürlüklerinin korunduğu, toplumu oluşturan gruplar arasında eşitliğe dayalı bir ilişki biçimi sağlamayı amaçlayan, çoğunluğun yönetimde söz sahibi olmasına, azınlığın ise haklarının gözetilmesine dayalı bir yönetim biçimidir. ${ }^{5}$

Demokrasi ve eğitim arasında karşılıklı etkileşime dayalı yakın bir ilişki vardır. Bir yandan eğitim, demokrasinin toplum içinde kabulü, toplumsal varlığı ve

1 Salih Zeki Genç, "Demokratik kazanımların gerçekleştirilmesinde ilköğretim öğretmenlerinin etkililiğinin değerlendirilmesi”, Milli Eğitim Dergisi 171 (2006): 43-54.

2 Gabriel Abraham Almond ve Sidney Verba, The civic culture: Political attitudes and democracy in five nations (Princeton university press, 2015), 52.

3 Fareed Zakaria, The future of freedom: illiberal democracy at home and abroad (Revised Edition) (WW Norton \& company, 2007), 63.

4 John Dewey, Democracy and education (Courier Corporation, 2004), 11.

5 Jürgen Habermas, Between facts and norms: Contributions to a discourse theory of law and democracy (John Wiley \& Sons, 2015), 13. 
sürdürülebilirliğini sağlarken; diğer yandan demokrasi, eğitimin kaliteli bir bilimsel çerçevede sürdürülmesi ve özgür bir ortamda bilimsel bilgi üretilmesine imkân tanır. ${ }^{6}$ Toplumsal yapının önemli bir unsuru olan demokrasinin temel değerleri her bireyi etkiler. Bireylerin demokrasi alg1 ve tutumları ise toplum genelinin demokratik değerleri içselleştirme derecesinin göstergesidir. ${ }^{7}$ Bu kapsamda demokratik tutum, okul içinde çalışan öğretmen ve yöneticilerin de etkilediği ve etkilendiği bir kavram olarak belirmektedir. Tutum, bireylerin belirli bir olgu, nesne, yapı, kavram veya kişi ile ilgili duygu, düşünce ve davranışlarının tutarlılı̆̆ını belirleyen yargısal eğilimi ifade eder. ${ }^{8}$ Demokratik tutum ise adalet, özgürlük, fırsat ve imkân eşitliği gibi asli insani kavram ve değerlerin, yasal sınırlar içerisinde belirli bir yaşantı haline getirilmesine öncülük eden davranış kalıbıdır. ${ }^{9}$

Din ve demokrasi kavramı sıklıkla tartışılmış; demokrasinin dinî alanları etkilemesi ve din kavramının demokrasi tanımını kapsama durumu klasik metinlerden günümüze değin farklı düşünürlerin çalışmalarına konu olmuştur. ${ }^{10}$ Din ve demokrasinin çelişkili ilişkisi, uzun bir geçmişe sahiptir. ${ }^{11}$ Hemen her dinî oluşumda belirli sınırlar içinde demokrasiyi kabul eden dinî anlayış olmasına karşın, teokratik temelleri benimseyen ve demokrasiyi tamamen reddeden bir dinî anlayış da bulunur. ${ }^{12} \mathrm{Bu}$ durumda toplumdaki demokratik tutumun, din temelli tartışmalardan etkilendiğ $i^{13}$, dinî eğitim veren kurumlar ile din eğitimi alanında çalışan öğretmenlerin, demokratik tutumlarının ve demokrasi algılarının toplumda eğitim hizmeti sunan diğer çevrelerden farklılaştı̆̆g düşüncesi ${ }^{14}$ bu çalışmanın yürütülmesindeki temel motivasyon kaynağıdır. Bunun yanında öğrencilerin tutum ve davranışları kazanmasında sosyal öğrenmenin önemi bilindiğinden, öğrenciye istendik demokratik tutumların kazandırılmasında din kültürü ve ahlak bilgisi öğretmenlerinin (DKAB) etkisi de çalışma kapsamında tartışılmıştır. Bu çalışma esasen $\mathrm{DKAB}$ öğretmenlerinin demokratik tutumlarını ve din eğitimi içerisinde demokrasi kavramının yerini belirlemek amacıyla yapılmıştır. İlerleyen bölümlerde eğitim, demokrasi ve din eğitimi kavramları ele alınmıştır.

6 Anthony Downs, "An economic theory of political action in a democracy", Journal of political economy 65, 2 (1957): 135-50; Zakaria, The future of freedom: illiberal democracy at home and abroad (Revised Edition), 57-59.

7 Habermas, Between facts and norms: Contributions to a discourse theory of law and democracy, 42.

8 Çiğdem Kağıtçıbaşı, "Yeni insan ve insanlar (10. baskı)", İstanbul: Evrim Yayınevi, 1999, 13-14.

9 Savaş Büyükkaragöz - Ö Üre, "Öğretmen yetiştiren yükseköğretim kurumlarındaki öğrencilerin demokratik tutumları araştırması”, Türk Demokrasi Vakfi Bülteni 19 (1994): 29-41.

10 Dennis C. Mueller, Reason, religion, and democracy (Cambridge University Press, 2009), 57.

11 Dewey, Democracy and education, 18.

12 Zakaria, The future of freedom: illiberal democracy at home and abroad (Revised Edition); Mueller, Reason, religion, and democracy, 54-59.

13 Almond ve Verba, The civic culture: Political attitudes and democracy in five nations, 49-51.

14 Hugh Lauder, "Education, democracy and the economy", British Journal of Sociology of Education 12, sy 4 (1991): 417-431; Dewey, Democracy and education, 88; Habermas, Between facts and norms: Contributions to a discourse theory of law and democracy, 102. 


\section{DEMOKRASİ VE EĞİTIM}

Tarihsel olarak insanlığın tüm düşünsel birikimine vurgu yapan demokrasi, kamusal alanda çoğunluğu oluşturan halkın iktidarı veya halkın, devlet politikalarının belirlenmesinde herhangi bir ayrıma uğramadan, eşit haklarının olduğu bir yönetim biçimi olarak tanımlanır. ${ }^{15}$ Temelde bir yönetim biçimi olarak tanımlanan demokrasi vatandaşların yaşam biçimini ve insanların varoluşsal haklarını da bünyesinde barındıran dinamik bir kavramdır. ${ }^{16}$ Kamusal alanın hızla değiştiği günümüzde, değişime yön veren demokratik pratikleri, devlet veya kurumsal yapılardan beklemek yerine, bireylerin tutum ve davranışlarını demokratikleştirmesi önemlidir. ${ }^{17}$ İnsanın bilgi, beceri ve tutumlarında, belirli bir kavrayış ve olgunluğu gerektiren demokratik davranışların edinilmesi ise kendiliğinden gerçekleşmemektedir. Eğitim, bireylerin demokratik tutum ve davranışlarına yön vermenin yanında onları yeniden üreterek demokrasi kavramının dinamikliğine katkı sağlar.

Demokrasi birlikte yaşama kültürü veya diğerlerinin yaşam alanlarına müdahale etmemek olarak tanımlandığında, bir tutumlar dizgesini ifade ederken ${ }^{18}$; diğerlerine karşı ön yargılardan uzak ve hoşgörülü olma olarak betimlendiğinde belirgin bir eylem kalıbına atıf yapmaktadır. ${ }^{19}$ Demokrasi, toplumda üretilirken aynı anda bireylerin zihniyet dönüşümleri ile kamusal alanda yeniden üretilir. Toplumsal üretim aracı olarak ifade edilen eğitim, bireyin demokratik tutum ve davranışları öğrenmesi ve içselleştirmesi gibi durumlarda önemli bir aygıttır. ${ }^{20} \mathrm{De}$ mokrasinin kamusal alanda tarihsel olarak gelişen ve yaygınlaşan etkisinin olması, eğitim süreci içinde yer alan tüm bileşenlerin demokratik değerler dizisini içerecek şekilde düzenlenmesini zorunlu kılar.

Sosyal öğrenme kuramı gereği, tutumlarımızın çoğu kendi dışımızdaki insanları gözleyerek ve onların eylem, tutum ve davranışlarını taklit ederek kazanılmaktadır. ${ }^{21}$ Öncelikle eğitim örgütlerinde hizmet sunan öğretmen, yönetici ve diğer personelin yaşantılarında egemen olan bir demokratik kültür, öğrenci ve veliler gibi eğitim hizmetlerinden yararlananlar tarafından da örnek alınacaktır. Zamanla eğitimin tüm süreçlerine yerleşecek olan demokratik kültür, eğitim felsefesinde radikal değişimlere yol açacak, böylelikle toplumda demokrasi bilinci ve demokratik yaşam değerlerinin içselleştirilmesi kolaylaşacaktır. ${ }^{22}$

15 Habermas, Between facts and norms: Contributions to a discourse theory of law and democracy, 103.

16 Charles Taylor, Multiculturalism: Examining the politics of recognition. (ERIC, 1994), 87.

17 Dewey, Democracy and education, 63.

18 Downs, "An economic theory of political action in a democracy", 69.

19 Nancy Fraser, "Rethinking the public sphere: A contribution to the critique of actually existing democracy", Social text, 25/26 (1990): 56-80.

20 Almond ve Verba, The civic culture: Political attitudes and democracy in five nations, 91.

21 Albert Bandura, "Social learning theory of aggression", Journal of communication 28/3 (1978): 12-29.

22 Dan Finn v.dğr., "Social democracy, education and the crisis", On Ideology, 10 (1978): 144. 
Kamusal alanda sosyal yaşantıların aktarımı ve karşılıklı etkileşimle demokratik içselleştirmenin sağlanabileceğini savunan Lauder ${ }^{23}$, demokrasinin kuramsal yaşantıdan ziyade pratik bir şekilde model alınarak ve bireyin öznel teması ile öğrenilebileceğini savunur. Lauder'e göre (1991) demokrasi, tolerans çerçevesi geniş ve bireylerin hak ve özgürlüklerine karşı belirli bir saygının söz konusu olduğu ortamlarda yaşanacak yoğun öznel temasla benimsenip içselleştirilebilir bir olgudur. Bu kapsamda eğitim çalışanlarının, çocuklara demokrasinin ne olduğunu değil nasıl yaşanacağını öğretmesi önemlidir. ${ }^{24}$ Bununla birlikte bu öğretinin etkisi, bilgi temelli olmaktan ziyade yaparak ve yaşayarak öğrenmelerle artacağından, öğretmenlerin de demokratik değerleri yaşıyor olması gereklidir. ${ }^{25}$

Kamusal alanda sanayi devrimi ile birlikte yaygınlaşan okul, bireylerin bütüncül bir şekilde geliştirilmesi ve toplumsal sisteme uyumlaştırılması gibi üst bir amaca sahiptir. ${ }^{26}$ Bunun yanında bireye verilen eğitim büyük ölçüde toplumca kabul görmüş istendik davranışlardır ve istendik tutum ve davranışların oluşturulması, yanlış veya hatalı olanların düzeltilip değiştirilmesi, okullarda planlı olarak verilen öğretim süreciyle gerçekleştirilir. ${ }^{27} \mathrm{Bu}$ süreçte başat aktör ise öğretmendir. Okul ortamında öğrenciyle aktif olarak temas eden ve onları etkileyen öğretmen, bu etkiyi öznel tutum ve davranışları ile oluşturur. Öğretmenlerin kendileri dışındakilere tepkileri, kalıp yargıları veya ön yargıları gibi bileșenler öğrencileri etkilemektedir. Söz konusu etki, tutumların aktarılabileceği yönünde yapılan farklı araştırmalarla ortaya konmuş ve sosyal etkinin sanılandan daha önemli olduğu belirlenmiştir. $^{28}$

Literatürde öğrencilerin, öğretmenlerin sinıfta sergilediği tutum ve davranışlarından etkilendiği belirlenmiştir. ${ }^{29}$ Öğretmenin davranış, karakter ve tutumunun öğrenciler üzerinde önemli bir etkisinin olabileceğini bildiren Skinner ve Belmont (1993), sınıflardaki öğretmen davranışlarının öğrenciye hızlı ve benzer şekilde etki ettiğini ve bu davranışların süreklilik kazanması durumunda ise öğrencilerde, öğretmen davranışlarının benzerlerinin görülebileceğini belirtmektedirler. Klem ve Connell (2004), öğretmen davranışlarının öğrenciler için yoğun bir motivasyon kaynağı olduğunu; öğretmenlerin demokratik ilke ve değerleri içselleştirmesinin, davranışlarında gözlenebilir farkllılıklar oluşturduğu ve öğrencilerin de

23 Lauder, "Education, democracy and the economy", 102-104.

24 Mueller, Reason, religion, and democracy, 74.

25 Gilles Saint-Paul - Thierry Verdier, "Education, democracy and growth", Journal of development Economics 42/2 (1993): 399-407.Gilles Saint-Paul ve Thierry Verdier, "Education, democracy and growth", Journal of development Economics 42, sy 2 (1993): 399-407.

26 Kysa Nygreen, "Negotiating Tensions: Grassroots Organizing, School Reform, and the Paradox of Neoliberal Democracy", Anthropology \& Education Quarterly 48/1 (2017): 42-60.

27 Lincoln Quillian, "New approaches to understanding racial prejudice and discrimination", Annu. Rev. Sociol. 32 (2006): 299-328.

28 Taylor, Multiculturalism: Examining the politics of recognition.; Dewey, Democracy and education, 77.

29 James Michael Lee, The flow of religious instruction: a social-science approach (Pflaum/Standard, 1973), 19-21. 
demokratik tutumları öğretmenlerini gözleyerek edindiklerini bildirmektedir. Öğretmenlerin demokratik tutum ve davranışları içselleştirmesi, yeni nesillerin istendik şekilde inşası için önemlidir. Bununla birlikte literatürde öğretmenlerin demokratik tutum ve davranışları sergileme düzeylerini gösteren sınırlı çalışma bulunmaktadır. ${ }^{30}$ Literatürdeki bazı çalışmalarda ise öğretmenlerin demokratik tutumlarının istenen seviyenin altında olduğuna ilişkin bulgulara ulaşılmıştır. ${ }^{31}$ Özetle eğitimcilerde demokratik tutumları haiz birtakım eksikliklerin olduğu ve önlemler alınması gerektiği görüşü bu araştırmanın yürütülmesindeki motivasyon kaynaklarından biridir.

\subsection{Din Eğitimi ve Demokrasi}

Dinler karakteristikleri gereği büyük ölçüde hoşgörüye dayalı bir demokratik bilinci barındırmaktadırlar. Demokrasinin güncel tartışmalarından ayrı olarak din kurumu, bireyin toplum içinde uyumu ve tolerans sınırlarının genişliğini artırmayı amaçlar. ${ }^{32}$ Benzer amaçların demokrasi kavramı içinde de yer alıyor olması önemlidir. Demokrasi, dinî ilke, kural ve değerlere aykırı olmayan tutum ve davranışlar içerirken üyelerine bu değerleri aktarmayı da görev kabul eder. ${ }^{33}$ Demokrasi ve din tartışmaları Batı dünyasında uzun bir tarihsel arka plana sahip olsa da Hristiyanlık ve Museviliğin genel anlamda demokrasi ile çelişmediği, buna karşın İslam’nn demokrasiden uzak olduğuna ilişkin söylemde bir yoğunlaşma olduğu görülür. ${ }^{34}$ İslam’a yönelik bu eleştirilerin kaynağını, İslam’ın yalnızca inanç esaslarını yaymaya çalışan bir öğreti olmadığı, bunun yanında dünyevi hayatın pek çok alanını yönlendiren bir yapısı olduğu düşüncesi oluşturur. ${ }^{35}$ Ayrıca demokrasinin seküler toplumsal yapılarda sürdürülebilir olduğu; ilahi irade ve manevi öğretilere dayalı İslam’ın demokrasinin bir gereği olan özgür akıl şartını yerine getiremeyeceği eleştirisi de yapılmaktadır. ${ }^{36}$ Bu nedenle Türk eğitim sistemi içerisinde zorunlu olarak sunulan din kültürü ve ahlak bilgisi derslerinde demokrasi olgusunun

30 Ronald L. Cohen, "Distributive justice: Theory and research", Social justice research 1/1 (1987): 19-40; H. Demirtaş, "Demokratik sınıf yönetimi ve üniversite öğrencilerinin öğretim elemanlarının sınıf yönetimi tutum ve davranışlarına ilişkin görüşleri”, XIII. Ulusal Eğitim Bilimleri Kurultayı. Malatya, 2004, 6-9; Deborah Meier, "So what does it take to build a school for democracy?", Phi Delta Kappan 85/1 (2003): 15-21; Amy Stuart Wells v.dğr., "Defining democracy in the neoliberal age: Charter school reform and educational consumption", American Educational Research Journal 39/2 (2002): 337-361.

31 Nygreen, "Negotiating Tensions: Grassroots Organizing, School Reform, and the Paradox of Neoliberal Democracy"; Georg Vanberg, "Democracy in chains and James M. Buchanan on school integration", Washington Post, 2017.

32 Mircea Eliade, The Myth of the Eternal Return: Cosmos and History translated by Willard R. Trask and Jonathan Z. Smith (NJ: Princeton University Press, 2005), 56-62.

33 Taylor, Multiculturalism: Examining the politics of recognition, 106.

34 Voll Esposito, John L. Esposito, ve John Obert Voll, Islam and democracy (Oxford University Press on Demand, 1996), 98.

35 Bernard Lewis, "A historical overview", Journal of Democracy 7/2 (1996): 52-63.

36 Eliade, The Myth of the Eternal Return: Cosmos and History translated by Willard R. Trask and Jonathan Z. Smith, 59. 
nasıl işlendiği; bu derslere giren öğretmenlerin demokrasi algisı ve demokrasiye yönelik tutumlarının nasıl olduğu gibi sorular, okullarda sunulan din eğitiminin demokrasiye yaklaşımının belirlenmesi açısından önem taşımaktadır.

Genel olarak din eğitimi, dinî bilgi ve pratiklerin yeni nesillere veya toplumda dinî eğitime ihtiyacı olan birey veya zümrelere aktarılmasıdır. Eğitim sistemi içinde özel ve ayrıcalıklı bir konumda olan din eğitimi konusu, Türkiye eğitim sistemi içinde çok kez değiştirilen ve sınırlarına en fazla müdahale edilen derstir. ${ }^{37}$ Din eğitimi alanında çalışan öğretmenlerin yeterlikleri konusu, yalnızca demokratik tutum yönünden değil aynı zamanda eğitim bilimlerine ilişkin yetkinlikler noktasında da tarihsel olarak tartışlagelmektedir. ${ }^{38}$ Eğitim sistemi içinde bireylerin dinî ihtiyaçlarını karşılayacak farklı tür ve kademede dinî eğitimler verilmektedir. Bununla birlikte DKAB öğretmenlerinin kişilik özellikleri, dine yönelik tutum ve davranışları, o dinin yeni nesillere sağlıklı olarak aktarılmasına etki edebilmektedir. ${ }^{39}$ Demokratik tutum ve davranışları sergileyen din eğitimcilerinin gerek okullarda gerek toplum içinde, demokrasinin daha fazla içselleştirilmesine katkı sağlayacağı görüşü bu araştırmanın ikincil motivasyon kaynağıdır.

Literatürde öncelikli demokratik öğretmen tutumları; temel iletişim becerileri gelişmiş, çatışma yönetimi konusunda yetkin, adil, hoşgörülü, anlayışl, nezaket kurallarına riayet eden, güvenilir, iyimser, kendisi gibi düşünüp yaşamayanlara karşı kalıp yargıları veya ön yargıları olmayan, öğrenciler arasında ayrımcılık yapmayan, katılımcı sınıf ortamı oluşturabilen nitelikler olarak belirlenmiştir. ${ }^{40}$ İdeal bir öğretmeni betimleyen söz konusu nitelikler demokrasi kültürünün ne denli istendik bir değerler dizgesi olduğunu belirlemektedir. Bunun yanında din eğitimcileri özelinde, demokratik tutumların önemi de yadsınamaz. ${ }^{41}$ Son yıllarda din eğitimi literatüründe, "DKAB öğretmeninin tutum ve davranışlarının, bireylere istendik dinî eğitimi vermenin önündeki önemli engellerden biri olduğu" düşüncesi çeşitli tartışma ve araştırmalara konu olmaktadır. ${ }^{42} \mathrm{Bu}$ çalışmada söz konusu tartı̧̧malara veri sağlamak çalışmanın motivasyon kaynaklarından biridir.

Dinî değerler ile demokratik değerleri harmanlayacak ve çağdaş toplumun ihtiyaçlarına cevap verebilecek bir eğitim sistemi kavramsal bilginin aktarılmasını

37 Cemal Tosun, “Din eğitimi bilimine giriş”, Pegem Atıf İndeksi, 2017, 26-32.

38 Recai Doğan ve Nurullah Altaş, "Din Öğretiminde Yeni Yöntem Tartışmalarında Kuramdan Uygulamaya: İlköğretim Din Kültürü ve Ahlak Bilgisi Programları (Ankara Modeli)”, Değerler Eğitimi Dergisi 2, sy 5 (2004): 23-38; Cemal Tosun, Din ve kimlik, c. 118 (Türkiye Diyanet Vakfı, 1993), 53.

39 Mueller, Reason, religion, and democracy, 96.

40 András Tilcsik, "Pride and prejudice: Employment discrimination against openly gay men in the United States", American Journal of Sociology 117/2 (2011): 586-626.

41 Lee, The flow of religious instruction: a social-science approach, 26-27.

42 Taylor, Multiculturalism: Examining the politics of recognition, 63; Quillian, "New approaches to understanding racial prejudice and discrimination", 93; Nygreen, "Negotiating Tensions: Grassroots Organizing, School Reform, and the Paradox of Neoliberal Democracy", 87. 
değil, bireylerde dinî ve demokratik yaşam pratiklerinin içselleştirilmesini sağlamalıdır. ${ }^{43}$ Toplumun ihtiyacı olan demokratik tutum ve davranışların içselleştirilmesi ise öğretmenlerin gerek okul içi gerek okul dışındaki tüm yaşantılarında demokratik tutumları sergilemelerini gerektirmektedir. ${ }^{44}$ Özellikle çocuklarda bilişsel, duygusal ve psikomotor gelişim sürecine yön veren ilköğretim (ilkokul ve ortaokul) sürecinde, öğrencilerde demokratik değerleri haiz kişilik geliştirilmesinde sınıf öğretmenlerinin olduğu kadar bu okullarda görev yapan DKAB öğretmenlerinin de rolü yadsınamaz. ${ }^{45}$ Söz konusu öğretmenlerin demokrasiye ilişkin sahip oldukları kuramsal bilgiye atıf yapan bir değer, tutum ve davranış dizgesine sahip olması gereklidir. Ayrıca din kavramıyla özdeşleşen DKAB öğretmenlerinin demokrasiyi aktif olarak yaşaması öğrencilere yansıyacak ve öğrenci tutumlarının kalıcı değişimine katkı sağlayacaktır. Bunun yanında demokratik tutumları sergileyen DKAB öğretmenleri, dinî yaşantının demokratik değerlerle uyumu konusunda da öğrencilere örnek olacaklardır. ${ }^{46}$

$\mathrm{Bu}$ araştırmanın amacı, DKAB öğretmenlerinin demokratik tutumlarının belirlenmesidir. Bu amaçla aşağıdaki sorulara yanıt aranacaktır:

1. DKAB öğretmenlerinin demokratik tutumları nasıldır?

2. DKAB öğretmenlerinin demokratik tutumlarını cinsiyet, eğitim durumu, mezun olunan bölüm ve mesleki kıdem değişkenleri farklılaştırmakta mıdır?

\section{YÖNTEM}

\subsection{Araştırma Deseni}

Araştırmada DKAB öğretmenlerinin demokratik tutumları güncel şekliyle betimlenmeye çalışıldığından, nicel araştırma yöntemlerinden betimsel tarama modeli ile tasarlanmıştır. Betimsel tarama modelinde araştırma problemi, kendi bağlamı içinde belirlenmeye çalışılmaktadır. ${ }^{47}$

\section{2. Çalışma Grubu}

Araştırma evreni, Ankara İlinin 25 ilçesinde resmî ilkokul, ortaokul ve ortaöğretim okullarında çalışan 2078 DKAB öğretmenidir. Araştırmada, evreni ayrıntıları ile yansıtabilmek için tabakalı örnekleme yöntemi kullanılmıştır. ${ }^{4}$ İlgili

43 Tosun, "Din eğitimi bilimine giriş", 37; Gunnar Myrdal, An American Dilemma: The Negro Problem and Modern Democracy, Volume 1 (Routledge, 2017), 45-46.

44 Nurullah Altaş, Gençlik döneminde din olgusu ve liselerde din öğretimi (Nobel, 2004), 18-20.

45 Nygreen, "Negotiating Tensions: Grassroots Organizing, School Reform, and the Paradox of Neoliberal Democracy", 81-83.

46 Taylor, Multiculturalism: Examining the politics of recognition.; Quillian, "New approaches to understanding racial prejudice and discrimination", 103-105.

47 Alan Bryman, “Integrating quantitative and qualitative research: how is it done?", Qualitative research 6/1 (2006): 97-113.

48 Ali Baltacı, "Nitel Araştırmalarda Örnekleme Yöntemleri ve Örnek Hacmi Sorunsalı Üzerine Kavramsal Bir 
örneklem teknikleri ile evreni en uygun şekilde temsil edecek örneklem sayısı 324 olarak hesaplanmıştır. Örneklem kapsamında belirlenen katılımcılara (DKAB öğretmenleri) 500 ölçek, araştırmacı tarafından elden ulaştırılmıştır. Araştırmada gönüllülük ilkesi esas alınmış; ölçekleri doldurmak istemeyenler zorlanmamıştır. Ölçeğin doldurulma süresi 15 dakika olup doldurulan ölçekler araştırmacı tarafından toplanmıştır. Bu bağlamda dağıtılan ölçeklerden 397'si geri dönmüştür. Bu ölçeklerden 37'si eksik veya yanlış doldurma, 11'i de uç değerlere sahip olmaları gerekçe gösterilerek analizden çıkarılmıştır. Örneklem büyüklüğü ölçütünü karşılayan ve hedef evrenin \%17'sini oluşturan 349 ölçek değerlendirmeye alınmıştır. Örnekleme ilişkin demografik bulgular Tablo 1'de görülmektedir.

Tablo 1

$D K A B$ öğretmenlerinin demografik bilgileri

\begin{tabular}{|c|c|c|c|c|}
\hline Değişkenler & Alt Kategoriler & $\mathrm{N}$ & $\%$ & Toplam \\
\hline \multirow{2}{*}{ Cinsiyet } & Erkek & 153 & 43,84 & \multirow{2}{*}{349} \\
\hline & Kadın & 196 & 56,16 & \\
\hline \multirow{2}{*}{ Eğitim Durumu } & Lisans & 227 & 65,04 & \multirow{2}{*}{349} \\
\hline & Lisansüstü & 122 & 34,96 & \\
\hline \multirow{2}{*}{$\begin{array}{l}\text { Mezun Olunan } \\
\text { Bölüm }\end{array}$} & İlahiyat Fakültesi & 199 & 57,02 & \multirow[b]{2}{*}{349} \\
\hline & $\begin{array}{c}\text { DKAB } \\
\text { Öğretmenliği }\end{array}$ & 150 & 42,98 & \\
\hline \multirow{3}{*}{ Mesleki Kıdem } & $1-5 \mathrm{yll}$ & 119 & 34,10 & \multirow{3}{*}{349} \\
\hline & $6-10$ yil & 122 & 34,96 & \\
\hline & 11 yll ve üstü & 108 & 30,95 & \\
\hline
\end{tabular}

Tablo 1 incelendiğinde, katılımcıların \%56,16’sı kadındır ve \%65,4’ü lisans düzeyinde eğitim almıştır. Ayrıca katılımcıların \%57,2'si ilahiyat fakültesi mezunu ve \%34,96'sının mesleki kıdemi ise 6-10 yıl arasında değişmektedir.

\subsection{Veri Toplama Aracı}

Bu çalışmada "Published for the Attitude Research Laboratory" tarafından geliştirilen ve Türk kültürüne uyarlanması Gözütok (1995) tarafından yapılan "Demokratik Tutum Ölçeği" kullanılmıştır. ${ }^{49}$ Uyarlama formu 32 olumlu ve 18

İnceleme”, Bitlis Eren Üniversitesi Sosyal Bilimler Enstitüsü Dergisi 7, sy 1 (2018): 231-274; Donald R. Cooper, Pamela S. Schindler, ve Jianmin Sun, Business research methods, c. 9 (McGraw-Hill Irwin New York, 2006), 63; Charles Teddlie ve Fen Yu, "Mixed methods sampling: A typology with examples", Journal of mixed methods research 1, sy 1 (2007): 77-100.

49 F. D. Gözütok, "Öğretmenlerin Demokratik Tutumları. Ankara: TDV (Türk Demokrasi Vakfı) Yayınları", An- 
olumsuz ifade olmak üzere toplamda 50 maddeden oluşan ölçeğin iç tutarlık katsayısı .87 olarak hesaplanmıştır. Bu çalışma kapsamında yapılan analizde ise ölçeğin iç tutarlık değeri .84 olarak belirlenmiştir. Ölçekten alınabilecek puan 0 ile 50 arasında değişmekte olup düşük puanlar, demokratik tutum düzeyinin de düşük olduğunu belirlemektedir. Bu araştırma kapsamında uygulanan ölçekte yer alan sorular Ek l'de yer almaktadır.

\subsection{Veri Analizi}

Ölçme aracıyla elde edilen veriler, SPSS programıyla analiz edilmiştir. Veri setinin hangi yöntem ile analiz edileceğini belirlemek için normallik testleri yapılmıştır. Bu noktada çarpıklık (skewness) değeri -.413 ve basıklık (kurtosis) değeri ise .753 olarak hesaplanmıştır. Söz konusu değerlerin \pm 1 arasında değiştiği belirlendiğinden, veri setinin normal dağıldığı ve parametrik testlerin kullanılabilir olduğu görülmüştür. Ancak parametrik testlerin kullanılması için varyansların da homojen olması gereklidir. ${ }^{50}$ Veri setine ilişkin homojenlik tespiti Levene testi kullanılarak gerçekleştirilmiş; cinsiyet, eğitim durumu ve mesleki kıdem değişkenleri kapsamında yapılan analizde anlamlılık (p) değerlerinin .05’ten büyük olduğu belirlenmiştir. Böylelikle veri setinin analizi için parametrik testlerin uygulanmasının daha uygun olduğuna karar verilmiştir. Değişkenler arasındaki farkın matematiksel anlamlılığının yanında uygulamada da anlamlı olması gerektiği görüşünden ${ }^{51}$ hareketle etki büyüklüğü de belirlenmiştir. Veri setine ilişkin etki büyüklüğü Cohen tarafından geliştirilen hesaplama $(d)$ ile belirlenmiştir. ${ }^{52}$ Etki değerinin (d) .2'den düşük olması "zayıf etki", .5 olması "orta şiddette etki" ve .8'den büyük olması ise "güçlü etki" olarak değerlendirilmiştir. Veri setine uygulanan tüm istatistiki yöntemler için anlam düzeyi $(\mathrm{p})<.05$ olarak belirlenmiştir. Demografik değişkenlerin çözümlenmesinde ve bağımlı değişkenlerle olan ilişkilerinin belirlenmesinde cinsiyet ve eğitim durumu değişkeni için t-testi ile mesleki kıdem değişkeni için tek yönlü varyans analizi (ANOVA) yapılmıştır. İlişkisel karşılaştırmalarda sınıflar arası farklılığın incelenmesi, Scheffe testi ile gerçekleştirilmiştir.

\section{BULGULAR}

Katılımcıların cinsiyet ve eğitim durumlarına göre demokratik tutum düzeylerine ilişkin bilgiler Tablo 2'de görülmektedir.

kara University. Journal of Faculty of Educational Sciences 40/1 (1995): 135-156.

50 Şener Büyüköztürk, "Sosyal bilimler için veri analizi el kitabı", Pegem Atıf İndeksi, 2017, 53-55.

51 J. W. Kotrlik ve H. A. Williams, "The incorporation of effect size in information technology, learning, information technology, learning, and performance research and performance research", Information Technology, Learning, and Performance Journal 21, sy 1 (2003), 1-2.

52 Marnie E. Rice ve Grant T. Harris, “Comparing effect sizes in follow-up studies: ROC Area, Cohen's d, and r", Law and human behavior 29, sy 5 (2005): 615-620. 
Tablo 2

Katılımcıların cinsiyet ve eğitim durumuna göre demokratik tutumları

\begin{tabular}{|c|c|c|c|c|c|c|c|c|}
\hline Değişkenler & Kategoriler & $\mathrm{N}$ & $\overline{\mathrm{X}}$ & ss & sd & $\mathrm{t}$ & $\mathrm{P}$ & Cohen's d \\
\hline \multirow{2}{*}{ Cinsiyet } & Erkek & 153 & 30.75 & 4.16 & \multirow{2}{*}{347} & \multirow{2}{*}{2.26} & \multirow{2}{*}{.012} & \multirow{2}{*}{.59} \\
\hline & Kadın & 196 & 32.48 & 3.68 & & & & \\
\hline \multirow{2}{*}{$\begin{array}{l}\text { Eğitim } \\
\text { Durumu }\end{array}$} & Lisans & 227 & 30.21 & 4.59 & \multirow{2}{*}{347} & \multirow{2}{*}{3.11} & \multirow{2}{*}{.001} & \multirow{2}{*}{.72} \\
\hline & Lisansüstü & 122 & 33.02 & 3.25 & & & & \\
\hline \multirow{2}{*}{ Mezuniyet } & İlahiyat & 199 & 31.54 & 3.99 & \multirow{2}{*}{347} & \multirow{2}{*}{0.59} & \multirow{2}{*}{.724} & \multirow{2}{*}{.24} \\
\hline & DKAB Öğt. & 150 & 31.69 & 3.85 & & & & \\
\hline
\end{tabular}

Tablo 2'de katılımcıların cinsiyetleri ile demokratik tutumları arasında anlamlı bir değişim olduğu belirlenmiştir $\left[\mathrm{t}_{(347)}=2.26 ; \mathrm{p}<.05\right]$. Demokratik tutumlar kadınlarda $(\bar{X}=32.48)$, erkeklere göre $(\bar{X}=30.75)$ daha yüksek düzeydedir. Araştırmanın bağımsız değişkeni olan cinsiyet, demokratik tutumları $\left(d_{\text {Cohen }}=.59\right)$ orta düzeyde farklılaştırmaktadır. Benzer şekilde katılımcıların demokratik tutumlarıyla eğitim durumları arasında anlamlı bir farklılık bulunmaktadır $\left[\mathrm{t}_{(347)}=1.72 ; \mathrm{p}<.05\right]$. Lisansüstü eğitim seviyesinde olan katılımcılar $(\bar{X}=33.02)$, lisans mezunlarına göre $(\bar{X}$ =30.21) daha fazla demokratik tutum sergilemektedirler. Araştırmanın bağımsız değişkeni olan eğitim durumu, demokratik tutumları $\left(d_{\text {Cohen }}=.72\right)$ orta düzeyde farklılaştırmaktadır. Bunun yanında katılımcıların mezun oldukları bölüme göre demokratik tutumları arasında anlamlı bir farklılı bulunmamaktadır ( $\mathrm{p}>.05)$. Katılımcıların mesleki kıdemleri ile demokratik tutumlarına ilişkin bulgular Tablo 3 'te incelenebilir.

Tablo 3

Katılımcıların demokratik tutumlarının mesleki kıdeme göre durumu

\begin{tabular}{|c|c|c|c|c|c|c|c|c|c|c|}
\hline Değişken & & Kategoriler & $\mathrm{N}$ & $\bar{X}$ & ss & sd & $\mathrm{F}$ & Cohen's $d$ & $\mathrm{p}$ & $\begin{array}{c}\text { Fark } \\
\text { (Scheffe) }\end{array}$ \\
\hline \multirow{3}{*}{$\begin{array}{l}\text { Mesleki } \\
\text { Kidem }\end{array}$} & 1 & 5 y1l ve altı & 119 & 32.64 & 3.63 & & & & & $1-2$ \\
\hline & 2 & 6-10 yil & 122 & 31.73 & 3.94 & $2 ; 346$ & 3.813 & .51 & .023 & $1-3$ \\
\hline & 3 & 11 yıl ve üstü & 108 & 30.49 & 4.19 & & & & & $2-3$ \\
\hline
\end{tabular}


Tablo 3'e göre, katılımcıların mesleki kıdemleri ve demokratik tutumları arasinda anlamlı bir fark bulunmaktadır $\left[\mathrm{F}_{(2 ; 346)}=3.813 ; \mathrm{p}<.05\right]$. Demokratik tutum ile mesleki kıdemin alt kategorileri arasındaki farklılık düzeyleri incelendiğinde, 11 yıl ve üstü mesleki kıdeme sahip olanların diğer gruplara göre daha az demokratik tutum sergilediği görülmektedir. Benzer şekilde 6-10 yıl arasında mesleki kıdeme sahip olan katılımcıların da 5 yıl ve altı mesleki kıdeme sahip olanlara göre daha az demokratik tutuma sahip olduğu belirlenmiștir. Bu noktada mesleki kıdemdeki artışın, demokratik tutuma ilişkin eğilimi azalttığı gözlenmiştir. Araştırmanın bağımsız değişkeni olan mesleki kıdem, bağımlı değişken olan demokratik tutumu $\left(d_{\text {Cohen }}=.51\right)$ orta düzeyde farklılaştırmaktadır.

\section{SONUÇ}

Araştırma bulgularına göre DKAB öğretmenlerinin ortalama demokratik tutum puanları 31.62 olarak belirlenmiştir. Demokratik tutum ölçeğinde alınabilecek en yüksek puanın 50 olduğu dikkate alınırsa bu değer orta seviyededir. Bu durum DKAB öğretmenlerinin demokratik tutum ve davranış sergileme açısından orta düzeyde oldukları şeklinde yorumlanabilir. Çalışmanın söz konusu bulgusu literatürdeki çeşitli araştırmalarla benzerlik göstermektedir. ${ }^{53}$ Ancak elbette din ve demokrasi kavramları arasındaki güncel tartışmaların, DKAB öğretmenlerinin demokratik tutumlarına yoğun şekilde yansımadığı görüşü de araştırmanın söz konusu bulgusunu destekler niteliktedir. Ayrıca DKAB öğretmenlerinin sahip oldukları insani değerler ile demokratik tutumları arasında bir bağ olabileceği ve aslında demokratik tutum ve eğilimlerin insani ve vicdani değerlerle ilişkili olduğu düşüncesi ${ }^{54}$ de söz konusu bulguya atfedilebilir.

Gelişimsel olarak aile, bireyde temel değerlerin oluşturulmasında başat bir konumdayken sosyalleşme ile birlikte okul da önemli bir değerleme kurumu olarak belirir. Geleneksel aile tasarımında demokratik kültürün benimsenmesi çeşitli zorluklar içermekteyken okulun sunduğu demokratik ortam, söz konusu değer kazanımını kalıcılaştırmakta ve hızlandırmaktadır. Okullarda öğrencilere yönelik sunulan demokratik değer transferi, uygun öğrenme ortamları ve öğretmenlerin demokratik tutum ve davranışları içselleştirdiği bir din öğretim programı ile sağlanabilir. Ayrıca okuldaki diğer çalışanlar da söz konusu demokratik değerleme sürecinde etkili olabilmektedir. Öğretmenler, öğrencilere sunacakları bilgi, beceri ve davranışlar ile değerleri kendi demokratik tutumları ile harmanlayarak etkile-

53 Carl D. Glickman, Revolutionizing America's Schools. The Jossey-Bass Education Series. (ERIC, 1998); Roger Betancourt - Suzanne Gleason, "The allocation of publicly-provided goods to rural households in India: on some consequences of caste, religion and democracy", World Development 28/12 (2000): 2169-2182; Mehmet Kamil Coşkun, "Din kültürü ve ahlak bilgisi öğretmenlerinin tükenmişlik düzeylerinin çeşitli değişkenlere göre incelenmesi”, Elektronik Sosyal Bilimler Dergisi 41/41 (2012).

Myrdal, An American Dilemma: The Negro Problem and Modern Democracy, Volume 1. 
şimli bir öğrenme ortamı hazırlamakta ve böylelikle öğrencilerinde demokratik değer gelişimini sağlamaktadırlar. Öğretmen davranışlarının, öğrencilerde istendik davranış değişimlerinin oluşturulmasında oldukça önemli olduğu görüşünden hareketle, öğrencilerde tutum ve davranış geliştirilmesinin temelde öğretmen davranışlarının taklit edilmesi ile mümkün olabileceği söylenebilir. Bununla birlikte bireyin belirli bir davranış sergilemesine kaynaklık teşkil eden eğilimler olarak da ifade edilebilen tutumlar, esasen öğrencilere kazandırılmak istenen davranışların belirleyicisidir. Bu radikal etkisinden dolayı öğretmen tutumlarının belirlenmesi ayrica elzemdir.

$\mathrm{Bu}$ çalışmada, DKAB öğretmenlerinin demokratik tutumları cinsiyete, mezun olduğu eğitim seviyesine ve mesleki kıdem değişkenlerine göre incelenmiştir. Değişkenler belirlenirken ilgili literatür incelenmiş ve demokratik tutumları etkileyebilecek değişkenlerin seçilmesine özen gösterilmiştir. Bu araştırma sonucunda kadın öğretmenlerin, erkeklere göre daha fazla demokratik tutum gösterdikleri ve cinsiyetin demokratik tutumlarla anlamlı bir şekilde farklılaştığı bulgusu, literatürdeki farklı çalışmalarla desteklenmektedir. Literatürdeki çalışmaların büyük çoğunluğunda, kadınların erkeklere göre daha demokratik tutum sergiledikleri ${ }^{55}$ bulgusuna karşın; bu çalışma sonucuyla çelişen bulgulara da rastlanılmıştır. ${ }^{56} \mathrm{Li}$ teratür dikkate alındığında, demokratik tutumların cinsiyet değişkeni ile açıklanmasının anlamlı olmadığı söylenebilir. Ancak sosyal bilimlerin doğası gereği, bir olgu farklı ve değişken özelliklere sahiptir ve çok sayıda bileşen tarafından etkilenebilmektedir. $\mathrm{Bu}$ durumda cinsiyetle ilgili kesin bir yargı oluşturmak yerine, demokratik tutumlar ile cinsiyet arasında yönü belirlenemeyen bir etkileşim olduğunu savunmak daha doğru olacaktır.

Benzer şekilde DKAB öğretmenlerinin demokratik tutumları ile eğitim durumları arasında anlamlı bir ilişki söz konusudur. Bu sonuç literatürdeki farklı araştırma bulgularıyla çelişmekteyken ${ }^{57}$; Nygreen (2017) ve Genç ve Kalafat'in

55 Savaş Büyükkaragöz, Ortäğretimde demokrasi eğitimi: öğretmen, öğrenci ve yöneticilerin demokratik tutum ve davranışları (Selçuk Üniversitesi Araştırma Fonu, 1989); Savaş Büyükkaragöz ve Şahin Kesici, "Öğretmenlerin hoşgörü ve demokratik tutumları”, Kuram ve Uygulamada Egitim Yönetimi Dergisi 2, sy 3 (1996): 353-65; A. Seda Saracaloğlu, "Beden Eğitimi Öğretmeni Adaylarının Demokratik Tutumları”, Ege Eğitim Dergisi 1, sy 1 (2001); Nygreen, "Negotiating Tensions: Grassroots Organizing, School Reform, and the Paradox of Neoliberal Democracy"; Myrdal, An American Dilemma: The Negro Problem and Modern Democracy, Volume 1; M. N. Gömleksiz ve AÜ Kan, "Eğitim fakültesi ve tezsiz yükssek lisans programlarına kayıtlı öğretmen adaylarının demokratik tutumlarının değerlendirilmesi (Fırat Üniversitesi örneği)”, Milli Eğitim Dergisi 178, sy 1 (2008): 44-64.

56 Jonathan Cohen, "The foundation for democracy: School climate reform and prosocial education", Journal of character education 10/1 (2014): 43-52; Demirtaş, "Demokratik sınıf yönetimi ve üniversite öğrencilerinin öğretim elemanlarının sınıf yönetimi tutum ve davranışlarına ilişkin görüşleri”; Meier, "So what does it take to build a school for democracy?"

57 Myrdal, An American Dilemma: The Negro Problem and Modern Democracy, Volume 1; Zihni Merey, Selahattin Kaymakçı, ve Gökçe Kılıçoğlu, "Öğrenci Konseyi Seçimlerinde Sosyal Bilgiler Öğretmen Adaylarının Demokratik Tutumları (Gazi Üniversitesi Örneği)”, Milli Eğitim Dergisi 41, sy 191 (t.y.): 191-209; Wells, Slayton, ve Scott, "Defining democracy in the neoliberal age: Charter school reform and educational consumption"; M. H. 
(2007) yaptığı araştırma bulgusuyla örtüşmektedir. Buna göre demokratik tutumlar, öğrenim durumuna göre anlamlı bir farklılık göstermektedir. Daha üst seviye öğrenim gören (lisansüstü düzey) öğretmenlerin demokratik tutum düzeyleri, alt seviyede öğrenim gören (lisans düzeyi) öğretmen adaylarının demokratik tutum düzeylerinden daha yüksektir. Böyle bir sonuca gerekçe olarak lisansüstü eğitim döneminde öğretmenlerin maruz kaldığı sosyal süreçlerin, onlarda demokratik tutum geliştirmelerine olanak tanıyacak deneyimler ihtiva ettiği öne sürülebilir. Habermas’ın (2015) da belirttiği üzere demokrasi, kamusal alanda belirli düzeyde sosyalleşme gerektirirken; demokratik tutum kazanımı genelde kamusal, özelde ise yaşam alanında güçlü bir sosyalleşmeye ihtiyaç duyar. DKAB öğretmenlerinin eğitim seviyesindeki artışın, onların demokratik tutumlarını yükseltici etki yapması Habermas'ın kamusal alandaki gereklilikler savını doğrulamaktadır.

Din eğitimini okulda kılavuzlayan kişi olarak öğretmenlerin, çocukta var olan dinî istidat ve kabiliyetleri ortaya çıkarması ve geliştirmesi beklenmektedir. ${ }^{58} \mathrm{Di}$ nin insanlık kadar eski olduğu, insanlığın bütün üstün değer, kavram ve duygularının; insan hakları, demokrasi, eşitlik, kardeşlik, feragat, diğerkâmlık ve insana saygının hep dinden geldiği sosyolojinin ortaya koyduğu gerçeklerdir. ${ }^{59}$ Bu noktada DKAB öğretmenlerinin demokratik tutumlarının önemi belirginleşmektedir. Türkiye’de DKAB öğretmenleri ilahiyat fakülteleri ile DKAB öğretmenliği mezunları arasından atanmaktadır. Her iki bölüm kendi içinde farklı bir eğitim programı uygulamaktadır. Geçmişte öğretmen olmak isteyen ilahiyat fakültesi mezunlarının öğretmenlik meslek bilgisi derslerini (pedagojik formasyon) ilahiyat programı dışında almaları gerekiyor iken 2017 yılından itibaren eğitim formasyon dersleri ilahiyat programları içine alınmıştır. Ayrıca aynı dönemde son mezunlarını veren DKAB öğretmenliği programları kapatılmıştır. Eğitim sistemi içinde şu anda hem ilahiyat hem de DKAB öğretmenliği mezunları öğretmen olarak çalışmaktadırlar. $\mathrm{Bu}$ araştırmanın bir bulgusu da söz konusu iki program alanından mezun olanların demokratik tutumları arasındaki değişimdir. Buna göre, ilahiyat fakültesi ile DKAB öğretmenliği bölümü mezunlarının demokratik tutumları anlamlı olarak farklılaşmamaktadır. Bu durum alanyazındaki farklı araştırmalarla benzerlik göstermektedir. $^{60}$

Ercoşkun ve A. Nalçacı, "Sınıf öğretmeni adaylarının empatik beceri ve demokratik tutumlarının incelenmesi”, Milli Ĕ̆itim Dergisi 180 (2008): 204-15.

58 Davut Işıkdoğan, "İlköğretim din kültürü ve ahlâk bilgisi öğretmenliği bölümü mezunu öğretmenlerin yeterlikleri”, Ankara Üniversitesi Sosyal Bilimler Enstitüsü,(Yayınlanmamış Doktora Tezi), Ankara, 2006.

59 Beyza Bilgin, Türkiye'de din eğitimi ve liselerde din dersleri (Emel Matbaacılık, 1980).

60 Işıkdoğan, "İlköğretim din kültürü ve ahlâk bilgisi öğretmenliği bölümü mezunu öğretmenlerin yeterlikleri”; M. Kamil Coşkun, "Din kültürü ve ahlak bilgisi öğretmenlerinin demokratik tutum düzeylerinin çeşitli değişkenler açısından incelenmesi”, EKEV Akademi Dergisi, 2011, 65-73; Büyükkaragöz, Ortäŏgretimde demokrasi eğitimi: öğretmen, öğrenci ve yöneticilerin demokratik tutum ve davranışlarl; Gözütok, "Öğretmenlerin Demokratik Tutumları. Ankara: TDV (Türk Demokrasi Vakfı) Yayınları”. 
Demokratik tutumlar, bireyin bilişsel ve duyuşsal gelişmişlik düzeyine vurgu yapar. Yaşamın ilk yıllarından itibaren gelişen demokratik tutumlar zaman içinde bireyin sosyalleşmesine bağlı olarak güçlenir ve içselleştirilir. Bu noktada bireyin yaşı arttıkça farklı sosyal ortamlara girme durumu ve sosyal yapıların getirdiği karakteristikleri içselleştirme düzeyinde de radikal dönüşümler olacaktır. ${ }^{61}$ Demokrasi alg1sı, bilişsel süreçlere vurgu yapar ve bireyin en azından soyut dönem bilişsel özellikleri göstereceği varsayımı üzerine kuruludur. Bunun yanında demokrasi, bireyde büyük ölçüde empati temelli duyuşsal algının olduğu varsayımına da sahiptir. Ancak her iki süreçte belirgin bir seviye kaydeden demokratik tutumlar, davranışsal olarak sergilenebilir. Bu açıdan yaş veya onun örgütsel sonucu olan mesleki kıdem değişkeni önem arz eder. Bu araştırma sonucunda belirlenen mesleki kıdemin, demokratik tutumlar ile anlamlı olarak farklılaştığı bulgusu önemlidir. Araştırma sonucuna göre mesleki kıdemdeki artış, demokratik tutumların gösterilme düzeyini azaltmaktadır. Bu sonuç literatürdeki farklı çalışmalarla desteklenmektedir. ${ }^{62}$ Ayrıca literatürde sınırlı da olsa bu bulguyla çelişen sonuçlara rastlanmaktadır. ${ }^{63}$ Özetle bu çalışma bulgusuna göre, mesleki kıdemin bireylerde demokratik tutum geliştirmede etkili olduğu söylenebilir. Ancak mesleki kıdemdeki artışın demokratik tutumları da artıracağı yönündeki beklenti bu çalışma ile karşılanamamış, buna karşılık yaş ve mesleki kıdem arttıkça bireylerin daha geleneksel davranış formlarını tercih edip uyguladıkları yönündeki kültürel kuram bu araştırma ile doğrulanmıştır.

Din kavramı gibi demokrasi de daha çok tecrübe edilerek öğrenilen gelişimsel bir olgudur. Tecrübelere dayalı öğrenme ise özünde bilişsel ve sosyal süreçleri barındırsa dahi taklit ya da model alma yoluyla da gerçekleşen bir sürece vurgu yapar. Din eğitiminin özü bireyin edindiği bilgiyi yaşamına yansıtması ve yaşamını bilgi esaslarına göre düzenlemesidir. DKAB öğretmenleri önemli bir rol model olarak hem dinî bilgi ve değerleri hem de din pratiklerini aktif olarak sergilemek ve bunları öğrencilere benimsetmekle mükelleftirler. Demokratik tutumlar tıpkı dinî bilgi ve uygulamalar gibi zaman içinde içselleştirilmektedir. Kamusal alanda bireyin sergilediği demokratik tutum ve davranışlar, diğer bireyleri ve toplumu da

61 Daron Acemoglu - James A. Robinson, Economic origins of dictatorship and democracy (Cambridge University Press, 2005).

62 Büyükkaragöz ve Kesici, “Öğretmenlerin hoşgörü ve demokratik tutumları”; Büyükkaragöz, Ortaöğretimde demokrasi eğitimi: öğretmen, öğrenci ve yöneticilerin demokratik tutum ve davranışları; Saracaloğlu, "Beden Eğitimi Öğretmeni Adaylarının Demokratik Tutumları"; Nygreen, "Negotiating Tensions: Grassroots Organizing, School Reform, and the Paradox of Neoliberal Democracy".

63 Coşkun, "Din kültürü ve ahlak bilgisi öğretmenlerinin tükenmişlik düzeylerinin çeşitli değişkenlere göre incelenmesi”; Gömleksiz ve Kan, "Eğitim fakültesi ve tezsiz yüksek lisans programlarına kayıtlı öğretmen adaylarının demokratik tutumlarının değerlendirilmesi (Fırat Üniversitesi örneği)”; Merey, Kaymakçı, ve Kılıçoğlu, "Öğrenci Konseyi Seçimlerinde Sosyal Bilgiler Öğretmen Adaylarının Demokratik Tutumları (Gazi Üniversitesi Örneği)"; Durmuş Kılıç, M. H. Ercoşkun, ve Ahmet Nalçacı, "Sınıf öğretmeni adaylarının demokratik tutumları”, Türkiye Sosyal Araştırmalar Dergisi 8, sy 2-3 (2004): 9-19. 
etkiler. Din eğitiminin önemli bir parçası olan hoşgörü, tahammül, farklılıkların gözetilmesi ve insanlar arası etkili iletişim, eş anlı olarak demokrasinin de önemli bileşenlerindendir. Öğrencileri dinî yaşantıya sevk edecek öğretmenlerin hoşgörülü ve demokratik değerleri içselleştirmiş olmaları, öğrencilerin demokratik tutum kazanımlarını da hızlandıracaktır. Bu noktada DKAB öğretmenlerinin demokratik tutumlarının belirlenmesi önemli olsa da zamanla, geleneksel yapıların normatif etkisiyle demokratik tutumların değişeceği de unutulmamalıdır.

Demokratik tutum gelişimi bilişsel ve duyuşsal bir süreci ifade ettiğinden, bireyde demokratik tutum gelişiminin izlenmesi için belirli aralıklarda ölçümleme yapmak önemlidir. Bu açıdan ileride yapılacak araştırmaların boylamsal bir düzenekte tasarlanması ve farklı gelişim düzeylerine hitap edecek çeşitlilikte kurgulanması önerilebilir. Ayrıca boylamsal çalışmalar, demokrasi kültürünün gelişim seyriyle ilgili önemli veri sunacaktır. Bu araştırma nicel bir desende tasarland1ğından, ileride yapılacak araştırmaların, olgular arasındaki ayrımı netleştiren nitel veya karma yöntemlerle kurgulanması önerilebilir. Son olarak bu araştırma Ankara ilinde sınırlı bir DKAB öğretmen grubunda yürütülmüştür; ileride yapılacak araştırmaların farklı il ve bölgeleri de kapsayacak şekilde genişletilmesi, demokrasi kültürünün yaygınlığının belirlenmesi açısından önerilebilir. Bununla birlikte özellikle din ve demokrasi ekseninde süren tartışmalara nicel veri sunmayı hedefleyen bu çalışmadan hareketle DKAB öğretmenlerin demokratik yaşama katılım biçimleri, karar stilleri ve demokrasi kavramına ilişkin anlayışları nitel ve nicel çalışmalarla ele alınabilir.

\section{KAYNAKÇA}

Acemoglu, Daron - Robinson, James A. Economic origins of dictatorship and democracy. Cambridge University Press, 2005.

Almond, Gabriel Abraham - Verba, Sidney. The civic culture: Political attitudes and democracy in five nations. Princeton university press, 2015.

Altaş, Nurullah. Gençlik döneminde din olgusu ve liselerde din öğretimi. Nobel, 2004.

Baltacı, Ali. "Nitel Araştırmalarda Örnekleme Yöntemleri ve Örnek Hacmi Sorunsalı Üzerine Kavramsal Bir İnceleme". Bitlis Eren Üniversitesi Sosyal Bilimler Enstitüsü Dergisi 7/1 (2018): 231-274.

Bandura, Albert. "Social learning theory of aggression". Journal of communication 28/3 (1978): 12-29.

Betancourt, Roger - Gleason, Suzanne. "The allocation of publicly-provided goods to rural households in India: on some consequences of caste, religion and democracy". World Development 28/12 (2000): 2169-2182.

Bilgin, Beyza. Türkiye’de din eğitimi ve liselerde din dersleri. Emel Matbaaclık, 1980.

Bryman, Alan. "Integrating quantitative and qualitative research: how is it done?" Qualitative research 6/1 (2006): 97-113.

Büyükkaragöz, Savaş. Ortaöğretimde demokrasi eğitimi: öğretmen, öğrenci ve yöneticilerin demokratik tutum ve davranışları. Selçuk Üniversitesi Araşııma Fonu, 1989. 
Büyükkaragöz, Savaş - Kesici, Şahin. “Öğretmenlerin hoşgörü ve demokratik tutumları”. Kuram ve Uygulamada Egitim Yönetimi Dergisi 2/3 (1996): 353-365.

Büyükkaragöz, Savaş - Üre, Ö. "Öğretmen yetiştiren yükseköğretim kurumlarındaki öğrencilerin demokratik tutumları araştırması”. Türk Demokrasi Vakfı Bülteni 19 (1994): 29-41.

Büyüköztürk, Şener. “Sosyal bilimler için veri analizi el kitabı”. Pegem Atıf İndeksi. 2017. $1-213$.

Cohen, Jonathan. "The foundation for democracy: School climate reform and prosocial education". Journal of character education 10/1 (2014): 43-52.

Cohen, Ronald L. "Distributive justice: Theory and research". Social justice research 1/1 (1987): 19-40.

Cooper, Donald R. - Schindler, Pamela S. - Sun, Jianmin. Business research methods. McGraw-Hill Irwin New York, 2006.

Coşkun, M. Kamil. "Din kültürü ve ahlak bilgisi öğretmenlerinin demokratik tutum düzeylerinin çeşitli değişkenler açısından incelenmesi”. EKEV Akademi Dergisi. 2011. 65-73.

Coşkun, Mehmet Kamil. "Din kültürü ve ahlak bilgisi öğretmenlerinin tükenmişlik düzeylerinin çeşitli değişkenlere göre incelenmesi”. Elektronik Sosyal Bilimler Dergisi 41/41 (2012).

Demirtaş, H. "Demokratik sınıf yönetimi ve üniversite öğrencilerinin öğretim elemanlarının sınıf yönetimi tutum ve davranışlarına ilişkin görüşleri”. XIII. Ulusal Eğitim Bilimleri Kurultayi. Malatya: 2004. 6-9.

Dewey, John. Democracy and education. Courier Corporation, 2004.

Doğan, Recai - Altaş, Nurullah. "Din Öğretiminde Yeni Yöntem Tartışmalarında Kuramdan Uygulamaya: İlköğretim Din Kültürü ve Ahlak Bilgisi Programları (Ankara Modeli)". Değerler Eğitimi Dergisi 2/5 (2004): 23-38.

Downs, Anthony. "An economic theory of political action in a democracy". Journal of political economy 65/2 (1957): 135-150.

Eliade, Mircea. The Myth of the Eternal Return: Cosmos and History translated by Willard R. Trask and Jonathan Z. Smith. NJ: Princeton University Press, 2005.

Ercoşkun, M. H. - Nalçacı, A. "Sınıf öğretmeni adaylarının empatik beceri ve demokratik tutumlarının incelenmesi”. Milli Eğitim Dergisi 180 (2008): 204-215.

Esposito, Voll - Esposito, John L. - Voll, John Obert. Islam and democracy. Oxford University Press on Demand, 1996.

Finn, Dan - Grant, Neil - Johnson, Richard. "Social democracy, education and the crisis". On Ideology. 10 (1978): 144.

Fraser, Nancy. "Rethinking the public sphere: A contribution to the critique of actually existing democracy". Social text. 25/26 (1990): 56-80.

Genç, Salih Zeki. "Demokratik kazanımların gerçekleştirilmesinde ilköğretim öğretmenlerinin etkililiğinin değerlendirilmesi”. Milli Ĕ̆itim Dergisi 171 (2006): 43-54.

Glickman, Carl D. Revolutionizing America's Schools. The Jossey-Bass Education Series. ERIC, 1998.

Gömleksiz, M. N. - Kan, AÜ. "Eğitim fakültesi ve tezsiz yüksek lisans programlarına kayıtlı öğretmen adaylarının demokratik tutumlarının değerlendirilmesi (Fırat Üniversitesi örneği)”. Milli Eğitim Dergisi 178/1 (2008): 44-64.

Gözütok, F. D. “Öğretmenlerin Demokratik Tutumları. Ankara: TDV (Türk Demokrasi 
Vakf1) Yayınları". Ankara University. Journal of Faculty of Educational Sciences 40/1 (1995): 135-156.

Habermas, Jürgen. Between facts and norms: Contributions to a discourse theory of law and democracy. John Wiley \& Sons, 2015.

Işıkdoğan, Davut. "İlköğretim din kültürü ve ahlâk bilgisi öğretmenliği bölümü mezunu öğretmenlerin yeterlikleri”. Ankara Üniversitesi Sosyal Bilimler Enstitüsü,(Yayınlanmamış Doktora Tezi), Ankara. 2006.

Kağıtçıbaşı, Çiğdem. "Yeni insan ve insanlar (10. baskı)”. İstanbul: Evrim Yayınevi. 1999.

Kılıç, Durmuş - Ercoşkun, M. H. - Nalçacı, Ahmet. "Sınıf öğretmeni adaylarının demokratik tutumları”. Türkiye Sosyal Araştırmalar Dergisi 8/2-3 (2004): 9-19.

Kotrlik, J. W. - Williams, H. A. “The incorporation of effect size in information technology, learning, information technology, learning, and performance research and performance research". Information Technology, Learning, and Performance Journal 21/1 (2003): 1.

Lauder, Hugh. "Education, democracy and the economy". British Journal of Sociology of Education 12/4 (1991): 417-431.

Lee, James Michael. The flow of religious instruction: a social-science approach. Pflaum/Standard, 1973.

Lewis, Bernard. "A historical overview". Journal of Democracy 7/2 (1996): 52-63.

Meier, Deborah. "So what does it take to build a school for democracy?" Phi Delta Kappan 85/1 (2003): 15-21.

Merey, Zihni - Kaymakçı, Selahattin - Kılıçoğlu, Gökçe. “Öğrenci Konseyi Seçimlerinde Sosyal Bilgiler Öğretmen Adaylarının Demokratik Tutumları (Gazi Üniversitesi Örneği)". Milli Eğitim Dergisi 41/191 (t.y.): 191-209.

Mueller, Dennis C. Reason, religion, and democracy. Cambridge University Press, 2009.

Myrdal, Gunnar. An American Dilemma: The Negro Problem and Modern Democracy, Volume 1. Routledge, 2017.

Nygreen, Kysa. "Negotiating Tensions: Grassroots Organizing, School Reform, and the Paradox of Neoliberal Democracy". Anthropology \& Education Quarterly 48/1 (2017): 42-60.

Quillian, Lincoln. "New approaches to understanding racial prejudice and discrimination". Annu. Rev. Sociol. 32 (2006): 299-328.

Rice, Marnie E. - Harris, Grant T. "Comparing effect sizes in follow-up studies: ROC Area, Cohen's d, and r". Law and human behavior 29/5 (2005): 615-620.

Saint-Paul, Gilles - Verdier, Thierry. "Education, democracy and growth". Journal of development Economics 42/2 (1993): 399-407.

Saracaloğlu, A. Seda. "Beden Eğitimi Öğretmeni Adaylarının Demokratik Tutumları”. Ege Eğitim Dergisi 1/1 (2001).

Taylor, Charles. Multiculturalism: Examining the politics of recognition. ERIC, 1994.

Teddlie, Charles - Yu, Fen. "Mixed methods sampling: A typology with examples". Journal of mixed methods research 1/1 (2007): 77-100.

Tilcsik, András. "Pride and prejudice: Employment discrimination against openly gay men in the United States". American Journal of Sociology 117/2 (2011): 586-626.

Tosun, Cemal. "Din eğitimi bilimine giriş”. Pegem Atıf İndeksi. 2017. 1-215.

Tosun, Cemal. Din ve kimlik. Türkiye Diyanet Vakf1, 1993. 
Vanberg, Georg. "Democracy in chains and James M. Buchanan on school integration". Washington Post. 2017.

Wells, Amy Stuart - Slayton, Julie - Scott, Janelle. "Defining democracy in the neoliberal age: Charter school reform and educational consumption". American Educational Research Journal 39/2 (2002): 337-361.

Zakaria, Fareed. The future of freedom: illiberal democracy at home and abroad (Revised Edition). WW Norton \& company, 2007.

\section{EK-1: Demokratik Tutum Ölçeği}

1. İnsanların amaçlarına saygılı olma, demokratik bir insanın en temel özelliğidir.

2. Öğrenciler okulda yarışma içinde olmalıdırlar. Çünkü ileriki yaşamlarında yarışma içinde olacaklardır.

3. Öğrenciler sınıf gösterileri ya da diğer grup etkinliklerine katılmaya teşvik edilmeli, ancak zorlanmamalıdır.

4. Öğrencilerin ihtiyaç duymaları halinde sınıfı terk etmek için öğretmenden izin almaları gerekir.

5. Öğrenciler sevmedikleri öğretmenlerin dersini almaya zorlanmamalıdır.

6. Demokratikleşme sürecindeki gelişme bilimdeki gelişmeden daha önemlidir.

7. Öğrenciler okul kantinini işletemeyecek kadar genç ve deneyimsizdirler.

8. Öğrencileri demokrasi uygulamaları için yüreklendirmek öğretmenlerin en yüce görevidir.

9. Gençlerin suç davranışlarının sıklığının ve ciddiyetinin artması, onların çok fazla özgür bırakılmalarının sonucudur.

10. Sınavların türleri ve zamanları öğretmenlerin kararıyla belirlenmelidir.

11. Sınıf düzeni ve disiplini, ilkokulun ilk yıllarından başlayarak, olabildiği kadar hızlı bir şekilde öğretmenlerin sorumluluğundan alınıp, öğrencilerin sorumluluğuna verilmelidir.

12. Öğrenci, öğretmenin otoritesini ya da düşüncesini sorgulamaya başladığında, yani kendisi için düşünmeye başladığında demokrasi işliyor demektir.

13. Türkiye’de eğitimcilerin zihnini kurcalayan sorunları kökünden ve uzmanca çözmeye çalışacak tam gün hizmet veren eğitim araştırmacıları olmalıdır.

14. Öğretmenin sıkı denetimi altında bulunan öğrenciler kölelerden farklı değildirler.

15. Çocuklara her denileni yapmak değil, düşünerek dürüstçe davranmak öğretilmelidir.

16. Okul yönetiminin aldığı kararları değiştirmede öğrencilerin etkisi olmalıdır.

17. Bir çocuğun mutlu olmayı öğrenmesi, okumayı öğrenmesinden daha önemlidir.

18. Günümüzde kullanılan "geleneksel öğretim yöntemlerinin” yerini "çağdaş öğretim yöntemlerinin” alması için bilimsel araştırmaların yapılması ihmal edilmiştir.

19. Amaçları başkaları tarafından belirlenen bir insan köledir.

20. Genci kendi değer yargılarıyla uyuşmayan şeyleri yapmaya zorlamak son derece yanlıştır.

21. Öğrencilerin öğretmenlere karşı tutumlarının araştırmalarla belirlenmesi gerekir.

22. Eğitim Politikaları belirleme konusunda, öğretmen ve öğrenci görüşüne gerek duyulmadan karar alma uygulaması sürdürülmelidir. 
23. Bir eğitim etkinliğinin değeri, öğrencilerin değerler sistemi açısından ölçülmelidir.

24. Öğrencilerin beğenileri, sinıflara ve koridorlara asılacak olan tablo ve resimlerin seçimini yapabilecek kadar gelişmemiştir.

25. Duyguların eğitimi, düşüncelerin eğitimi kadar önemlidir.

26. "Zorunlu" sorumluluk, gerçek sorumluluk değildir.

27. Öğrencilerin okulda sakız çiğnemelerine izin verilmemelidir

28. Öğrencilerin 10'da 9'unun karşı olduğu herhangi bir okul kuralı değiştirilmelidir.

29. Ev ödevlerinin belirlenmesi öğrencilerin kararına bırakılmamalıdır, bu ancak öğretmenler kurulunun karar yetkisinde olmalıdır.

30. Bireysel özgürlük, ancak gerekli olduğunda, grubun ilerlemesine engel olduğu durumlarda bireyin onayı alınmadan başkaları tarafından sınırlandırılabilmelidir.

31. Çocuğun ilgilerinden çok ihtiyaçlarının dikkate alınması, tüm eğitim kurumlarının benimsediği ilke olmalıdır.

32. Demokrasi, otokrat öğretmenler yerine görüşleri özgürce eleştirilebilen, hiçbir zaman zorlayıcı olmayan uzman öğretmenler olduğu takdirde arttırılabilir.

33. Bireylerin amacının kutsallı̆̆ 1 , demokrasinin özü olarak vurgulanabilir.

34. Demokratik bir okulda okul müdürüne gerek yoktur. Okul yaşamıyla ilgili kararlar öğrenci ve öğretmenlerin katılımıyla alınmalıdır.

35. Öğrencilerin az bildikleri ya da hiç bilmedikleri konularla ilgili görüşlerini söylemelerine izin verilmemelidir.

36. İdeal demokrasi herkese amaçlarını gerçekleştirme hakkı verir.

37. Okulun, öğretmenler tarafından belirlenmiş kesin kuralları olmalıdır.

38. Gerçekten demokratik olan öğretmenlerin eğer özgürlük için gerekliyse, sınıfta bir miktar düzensizliği hoş görmeleri ve buna izin vermeleri gerekir.

39. En iyi öğretmenler, sınıf atmosferi ile değil, öğretim konusu ile ilgilenirler.

40. Ciddi davranış bozuklukları; öğrencilerin yönetime katılmalarına izin verildiği okullarda görülür.

41. Öğretim programlarına sıkı bağlılık, sınıftaki demokratik yaşamın en büyük düşmanidir.

42. Uygulanamayan demokrasi öğrenilemez.

43. Demokratik yöntemle kazanılan bilgiler kalıcı ve gerçek bilgilerdir.

44. Sınıfta, yakında bir dükkânda çıkan yangın konusundan verilecek ders konusunda daha az saman ayrılmalıdır.

45. Öğrencilerin sınıfta oturacakları yeri kendilerinin seçmelerine izin verilmemelidir.

46. Sınıfta yapılan oylamalarda öğrencilerin kapalı oy hakkı olmalıdır.

47. Öğretmenlerin, öğrencilerin amaçlarına saygı göstermeleri, çocukların da büyüklerine saygı göstermelerine neden olur.

48. Çocukları özgür olan bir ulus, özgür insanları olan bir ulus olacaktır.

49. Bir sınıftaki öğrencileri için "iyi niyetli despot bir öğretmen, tam ve kontrolsüz özgürlük tanıyan bir öğretmenden” daha iyidir.

50. Sağlıklı, demokratik bir toplumda gençler için yarışmalı oyunlar ve sporlar önemlidir. 